\title{
Scientific theology behind the importance of collecting cremated ashes of COVID-19 dead patients
}

\begin{abstract}
The purpose of this short review is to understand that the cremated ashes of COVID-19 deceased patients are non-infectious and safer to store. The Cremation Association of North America states that these cremains have a more identifiable human connection. Like any of us, who love to hold our deceased ones dearer this pandemic has raised several doubts and worries whether it is safe to collect their ashes as these viruses could spread from the ashes too.
\end{abstract}

Volume 9 Issue I - 202 |

\author{
Keerthana P,Ananda Kumar S \\ Department of Chemistry, Anna University, India
}

Correspondence: Ananda Kumar S, Department of Chemistry, Anna University, India, Tel 984I73058I,

Email srinivanand@gmail.com

Received: July 09, 2020 | Published: February 19, 2021

\section{Introduction}

'Antyesti samskar' known as the 'last sacrifice' is the act of performing the funeral rights for the deceased ones in India. As we learn from the Holy Scriptures written, the human body and the whole universe have five elements in common I.e. air, water, fire, earth and space. The earth symbolises our sensory organs or life that perish, but the elements/atoms are eternal. After death, the atoms disintegrate and return to their original state. Space is the element that unites all the living organisms on earth. It has sound waves carried. Air is the most important element that acts as a driving force to every form of living. It is inevitable, and provides strength to move electrons around its nucleus. Water represents a cycle of life that is believed to return. It changes its state from water to vapour and returns back to the earth in form or rain and other water bodies. Fire denotes purity and the spirit of life. These last rites performed are to free the soul from its body and to return the body to that 5 elements and its origins. The 'cremains', called as the 'ashes' are then collected and usually immersed in the holy water. Swami Avedananda in his book "Life beyond death" has said that Cremation removes the chances of disease outbreak. It removes the disease causing pathogens along with its contaminants. With perspective to the dead, the importance of cremation is to purify the soul and return it to the universe (sukshma sharir). According to an Indian saint, if the ashes are not properly spread to a large space, it might cause physical, physiological changes and weaken your minds. It's prone to adolescents mainly.

\section{Discussion}

The temperature generated by the body while burning when it is placed in the cremated box is around 800-1000 degree Celsius. All the organs and soft tissues usually vaporize and get oxidized by the amount of heat and gases released during the cremation process. A Civil surgeon Dr Manjit Singh has said that if the prescribed protocol is being followed, the cremation of COVID-19 positive patients' bodies and even the ashes do not pose any risk. Sun Yat-sen University, China have produced the world's first lab-grown copies of SARS-CoV-2 published that "Temperature could significantly change COVID-19 transmission, as this virus is highly sensitive to high temperatures. Recently, researches have predicted the risks caused by the virus with the help of weather modelling. Major disease outbreaks are found in a number of cities and regions exclusively along the narrow east-west line roughly along the 30-50 North latitude corridor at a consistent weather pattern (5-11 degrees C [41 to $51 \mathrm{~F}]$ and 47-79 percent humidity). Aix-Marseille University researchers in southern France discovered that the SARS-CoV-2 coronavirus is able to withstand high temperatures till 60 degrees Celsius for an hour. They also found that they could render the virus completely inactive upon further heating the samples to 92 degrees Celsius for 15 minutes. Jeremy Rossman from University of Kent, U.K reported the inactivation of low levels of virus in most human cases at $56^{\circ} \mathrm{C}$, while Lancet Microbe found that at $70^{\circ} \mathrm{C}$ the virus was made completely inactive. It was stable only till $4^{\circ} \mathrm{C}$. As per WHO, the coronavirus in the cell culture supernatant usually gets killed at $56^{\circ} \mathrm{C}$ at around 10000 units per $15 \mathrm{~min}$. Rudi virus, a noted virus that lives in extreme temperatures up to $80^{\circ} \mathrm{C}$. An article on various viruses and their inactivation temperatures was published by E C Pirtle and G W Beran. Hence no virus is so far reported to withstand more than $1000^{\circ} \mathrm{C}$, a temp at which a dead body is burnt (Table 1).

Table I Various viruses and their inactivation temperatures

\begin{tabular}{|c|c|c|}
\hline S no. & Type of virus & Temperature and its source \\
\hline I. & $\begin{array}{l}\text { Adenovirus I2. Reovirus I, } \\
\text { and herpes simplex virus }\end{array}$ & $65^{\circ} \mathrm{C}$ in the suspension medium \\
\hline 2. & $\begin{array}{l}\text { Aujeszky's disease virus } \\
\text { (ADV) }\end{array}$ & $\begin{array}{l}\text { Suspended in saliva or nasal- } \\
\text { washing fluids. Moist at } 25^{\circ} \mathrm{C} \text {. } \\
\text { Inactivated within days }\end{array}$ \\
\hline 3. & Iridovirus & $\begin{array}{l}\text { Cannot survive beyond } \mathrm{pH} 4.0 \\
\text { for several hours. }\end{array}$ \\
\hline 4. & Rinderpest virus & $\begin{array}{l}\text { inactivated quickly outside the } \\
\text { body and was stable at } \mathrm{pH} 4.0 \text { - } \\
10.2 \text { at } 4^{\circ} \mathrm{C} \text {. }\end{array}$ \\
\hline 5. & Swine enterovirus & inactivated within $30 \mathrm{~min}$ at $50^{\circ} \mathrm{C}$ \\
\hline 6. & $\begin{array}{l}\text { Swine vesicular disease } \\
\text { virus }\end{array}$ & $\begin{array}{l}\text { Inactivated at or above } 60^{\circ} \mathrm{C} \text { for } \\
\text { at least } 30 \mathrm{~min}\end{array}$ \\
\hline 7. & Poliovirus & $\begin{array}{l}\text { Inactivated at pasteurization } \\
\text { temperatures, } 61.7^{\circ} \mathrm{C} \text { for } 30 \mathrm{~min} \\
\text { or } 7 \mathrm{I} .1^{\circ} \mathrm{C} \text { for } 15 \text { seconds. }\end{array}$ \\
\hline 8. & Coxsackie viruses & $\begin{array}{l}\text { thermally inactivation at } 55^{\circ} \mathrm{C} \\
\text { for } 15 \text { min or at } 71.1^{\circ} \mathrm{C} \text { for } 15 \\
\text { seconds in water. }\end{array}$ \\
\hline
\end{tabular}




\section{Conclusion}

In summary, the cremated ashes are a disintegrated matter of dry calcium phosphates with sodium and potassium salts. These ashes constitute the leftovers of unburnt bone mineral and tooth enamel. Cremation appears to be a sustainable funeral practice as they do not occupy land space, release toxic chemicals or consume valuable energies besides cremated ashes find unique applications. These ashes are used to build concrete reefs that are eco-friendly serving as a natural habitat for aquatic animals. They are mixed with growth mediums, nourishments and soil to act as manure to grow trees. (Bio urns) A US patent (US20080134575A1) is filed where a soil additive mixture is prepared using cremated ashes serving rich content of phosphorus source, promoting plant growth, and acting as a whole nutrient compost. Similar patents are filed based on methods to remove organic substances in ashes, produce biocompatible soil mixture from cremated ashes, soil table stability and designing biodegradable urns and containers using ashes. The carbon present in these ashes are extracted by intensive heat and pressure and mimicked into diamond gems. Other artifacts include cremated crystals, rings, glass, stones, fireworks, tattoos etc. providing a greener afterlife. Owing to the above reasons, it is clearly understood that cremation appears to be an ideal and safe process both in terms of scientific and cultural perspective to inactivate the viruses present in a dead body. Hence, it is safe to collect the cremated ashes of covid positive patients.

\section{Acknowledgments}

This article is dedicated to the loving memory of my dear grandfather Mr. Shanmugha Sundaram, who lost the battle fighting COVID-19. My sincere thanks to Dr. Anand Kumar, Associate professor, Department of Chemistry, Anna University for being my true strength and encouraging me to write this article.

\section{Conflicts of interest}

The authors declare that there is no conflict of interest.

\section{References}

1. Chan KH, Malik Peiris JS, Lam SY, et al. The Effects of Temperature and Relative Humidity on the Viability of the SARS Coronavirus. Adv Virol. 2011;7:734690.

2. Neeltje van Doremalen, Dylan H Morris, et al. Aerosol and Surface Stability of SARS-CoV-2 as Compared with SARS-CoV-1. N Engl J Med. 2020; 382:1564-1567.

3. Pirtle EC, Beran GW. Virus survival in the environment . Rev sci tech Off int Epiz. 1991;10:733-748.

4. Boris Pastorino, Franck Touret, Magali Gilles, et al. Evaluation of heating and chemical protocols for inactivating SARS-CoV-2. bioRxiv.2020.

5. Sajadi, Mohammad M, Habibzadeh, et al. Temperature, Humidity and Latitude Analysis to Predict Potential Spread and Seasonality for COVID-19. SSRN. 2020.

6. Racquel Zapanta Le Geros. Calcium Phosphate-Based Osteoinductive Materials. Chemical Reviews. 2008;108:4742-4753.

7. India Today.in. Burial or cremation: What is a safer funeral if someone dies of Covid-19?

8. Timesofindia.indiatimes.com. Cremating, burying bodies of covid-19 victims is safe: civil surgeon.

9. World Health Organization. First data on stability and resistance of SARS coronavirus compiled by members of WHO laboratory network.

10. John Stuart Thomson. China revolutionized, 1913. 